\title{
Megakaryocyte-Potentiating Factor
}

National Cancer Institute

\section{Source}

National Cancer Institute. Megakaryocyte-Potentiating Factor. NCI Thesaurus. Code C128317.

Megakaryocyte-potentiating factor (250 aa, $27 \mathrm{kDa}$ ) is encoded by the human MSLN gene. This protein plays a role in megakaryocyte colony formation. 